\title{
Effect of Sustained Maternal Hyperglycaemia on the Fetus in Normal and Diabetic Pregnancies
}

\author{
N. W. OAKLEY， R. W. BEARD， R. C. TURNER
}

British Medical fournal, 1972, 1, 466-469

\section{Patients and Methods}

Glucose infusions were performed at the time of artificial rupture of the membranes, before the onset of labour, in two groups of patients*-firstly, a normal group of eight women without a history suggestive of diabetes and, secondly, a group of five gestational diabetics treated during pregnancy by diet alone. Four patients with severe insulin-treated diabetes who received single $25-\mathrm{g}$ glucose loads also contributed glucose data to the diabetic group; the glucose assimilation of these patients was so impaired that a single pulse was enough to maintain a fairly uniform degree of hyperglycaemia for at least an hour. The patient groups were comparable with respect to body weight and no subject was grossly obese. The duration of gestation was not comparable, the normal pregnancies being induced at 40 to 42 weeks, usually for postmaturity, and the diabetics at 38 weeks, according to usual practice. All patients gave informed consent to the procedure.

In previous studies (Beard et al., 1971) glucose pulses were given to 21 normal subjects and to 9 gestational diabetics, whose fasting glucose and insulin values were directly comparable to those of the present groups of patients. These data have been pooled with the infusion series to give a "cumulated patient series"; this larger group increases the information available for statistical analysis and provides a check on the consistency of the methodology.

Mothers undergoing surgical induction of labour, regardless of whether they were normal or diabetic, fasted for 12 hours before the study. The insulin-treated diabetics, all on controlled carbohydrate diets with twice-daily injections of soluble isophane insulin mixtures, were deprived of insulin on the morning of induction.

After artificial rupture of the membranes and before the onset of labour capillary blood was collected from the fetus by means of the Saling technique (Saling, 1964). This type of sampling has been in routine clinical use for the management of women with high-risk pregnancies during labour over the past six years. At the same time blood was taken from an antecubital vein of the mother. A priming dose of $25-75 \mathrm{ml}$ of $50 \%$ glucose was then given intravenously to the mother, followed by a continuous infusion of $50 \%$ glucose at the rate of $0.3-1.5 \mathrm{ml} /$ min, usually lasting 70 minutes. During this period the fetal heart rate and fetal blood $\mathrm{pH}$ were monitored. Serial maternal and fetal blood samples were collected simultaneously at 10-minute intervals throughout the period of the infusion. Blood samples were taken into heparinized tubes, centrifuged, and the plasma was deep frozen until required for assay. Glucose was determined by the method of Cramp (1967) and immunoreactive insulin by that of Albano, Ekins, Maritz, and Turner (1972) using human insulin standards (Novo monocomponent human insulin or Lilly human insulin) and guineapig anti-pork-insulin sera, which have been shown to give identical results to those used in our previous studies (Turner, Oakley, and Nabarro, 1971).

\section{Results}

GLUCOSE VALUES

Results for individual patients are shown in Tables I and II. Mean fasting maternal and fetal glucose and insulin values are

- Clinical details may be obtained from N.W.O.
Institute for Clinical Research, Middlesex Hospital, London W.1

R. C. TURNER, M.B., B.CHIR., M.R.C.P., Leverhulme Research Fellow (Present address: Radcliffe Infirmary, Oxford) 
TABLE I-Infusion Series. Glucose and Insulin Values for Individual Patients not Receiving Insulin

\begin{tabular}{|c|c|c|c|c|c|c|c|c|c|}
\hline \multirow{3}{*}{ Group } & \multirow{3}{*}{$\begin{array}{l}\text { Case } \\
\text { No. }\end{array}$} & \multirow{3}{*}{$\underset{\text { Fetal }}{\text { Maternal } /}$} & \multicolumn{3}{|c|}{ Plasma Glucose $(\mathrm{mg} / 100 \mathrm{ml})$} & \multicolumn{4}{|c|}{ Plasma Insulin $(\mu \mathrm{U} / \mathrm{ml})$} \\
\hline & & & \multirow{2}{*}{ Fasting } & \multicolumn{2}{|c|}{ Infusion Plateau } & \multirow{2}{*}{ Fasting } & \multirow{2}{*}{$10 \mathrm{~min}}$. & \multirow{2}{*}{$50 \mathrm{~min}}$. & \multirow{2}{*}{$\begin{array}{c}\text { Peak Value } \\
\text { (Time in Minutes) }\end{array}$} \\
\hline & & & & Mean & Range & & & & \\
\hline Normal & $\begin{array}{l}1 \\
2 \\
3 \\
4 \\
5 \\
6 \\
7 \\
8\end{array}$ & $\begin{array}{l}\text { M. } \\
\text { F. } \\
\text { F. } \\
\text { M. } \\
\text { F. } \\
\text { M. } \\
\text { F. } \\
\text { M. } \\
\text { F. } \\
\text { M. } \\
\text { M. } \\
\text { F. } \\
\text { M. } \\
\text { F. }\end{array}$ & $\begin{array}{l}51 \\
44 \\
63 \\
71 \\
62 \\
65 \\
60 \\
87 \\
65 \\
76 \\
70 \\
65 \\
60 \\
62 \\
66\end{array}$ & $\begin{array}{l}151 \\
132 \\
224 \\
146 \\
182 \\
151 \\
234 \\
175 \\
277 \\
180 \\
287 \\
275 \\
285 \\
196 \\
204 \\
196\end{array}$ & $\begin{array}{l}142-162 \\
130-134 \\
215-228 \\
130-157 \\
164-193 \\
144-156 \\
218-245 \\
164-184 \\
267-287 \\
180-180 \\
278-296 \\
275-275 \\
281-294 \\
170-212 \\
195-216 \\
193-198\end{array}$ & $\begin{array}{r}15 \cdot 2 \\
15 \cdot 7 \\
20 \cdot 3 \\
11 \cdot 5 \\
12 \cdot 5 \\
8 \cdot 7 \\
8 \cdot 0 \\
18 \cdot 0 \\
45 \cdot 0 \\
17 \cdot 0 \\
22 \cdot 0 \\
10 \cdot 3 \\
13 \cdot 0 \\
13 \cdot 5 \\
7 \cdot 0 \\
10 \cdot 0\end{array}$ & $\begin{array}{r}82 \cdot 5 \\
17 \cdot 5 \\
69 \cdot 3 \\
8.2 \\
71 \cdot 0 \\
25 \cdot 8 \\
101 \\
23.0 \\
168 \\
19 \cdot 0 \\
115 \\
22 \cdot 0 \\
168 \\
22 \cdot 3 \\
91 \cdot 0 \\
11.0\end{array}$ & $\begin{array}{c}91 \cdot 7 \\
21 \cdot 0 \\
160 \\
26 \cdot 2 \\
66 \cdot 0 \\
114 \\
42 \cdot 5 \\
180 \\
135 \\
156 \\
42 \cdot 0 \\
39 \cdot 0 \\
17 \cdot 8\end{array}$ & $\begin{array}{c}105 \cdot 7(60) \\
26 \cdot 7(60) \\
240(70) \\
37.5(110) \\
71.0(10) \\
27.5(25)^{*} \\
120(60) \\
65.0(90) \\
180(60) \\
19.0(10)^{*} \\
170(80) \\
33.0(30)^{*} \\
195(60) \\
87.7(60) \\
113(90) \\
31.7(70)\end{array}$ \\
\hline $\begin{array}{l}\text { Gestational } \\
\text { diabetic }\end{array}$ & $\begin{array}{r}9 \\
10 \\
11 \\
12 \\
13\end{array}$ & $\begin{array}{l}\text { M. } \\
\text { F. } \\
\text { M. } \\
\text { F. } \\
\text { M. } \\
\text { F. } \\
\text { M. } \\
\text { F. } \\
\text { M. } \\
\text { F. }\end{array}$ & $\begin{array}{l}82 \\
47 \\
70 \\
35 \\
65 \\
45 \\
87 \\
70 \\
94 \\
66\end{array}$ & $\begin{array}{l}189 \\
128 \\
198 \\
153 \\
244 \\
158 \\
322 \\
175 \\
241 \\
172\end{array}$ & $\begin{array}{l}188-190 \\
120-132 \\
192-204 \\
140-164 \\
240-250 \\
153-163 \\
315-329 \\
160-190 \\
231-247 \\
160-190\end{array}$ & $\begin{array}{r}12 \cdot 5 \\
24 \cdot 5 \\
14 \cdot 0 \\
15 \cdot 2 \\
17 \cdot 5 \\
12 \cdot 5 \\
7 \cdot 5 \\
19 \cdot 3 \\
29 \cdot 0\end{array}$ & $\begin{array}{c}25.5 \\
29.5 \\
48.0 \\
31.0 \\
100 \\
30.0 \\
23.0 \\
35.8 \\
62.0 \\
56.0\end{array}$ & $\begin{array}{c}29.5 \\
29 \cdot 0 \\
26.0 \\
102 \\
100 \\
29 \cdot 0 \\
18.6 \\
30.7 \\
64.0 \\
43.0\end{array}$ & $\begin{array}{r}29 \cdot 5(45) \\
29 \cdot 5(10) \\
48 \cdot 0(10) \\
137 \quad(60) \\
115(70) \\
42 \cdot 0(30) \\
23 \cdot 0(10) \\
35 \cdot 8(10) \\
73 \cdot 0(85) \\
125(85)\end{array}$ \\
\hline
\end{tabular}

* No later samples.

shown in Table III, in which the figures in parentheses refer to the "cumulated patient series." Mean plateau glucose values for the infusions are set out in Table IV.

There was good agreement between the infusion series and the cumulated patient series with respect to all the values calculated; however, certain differences between normal and diabetic pregnancies reached statistical significance only in the larger group. The mean fasting maternal glucose concentration was higher in the gestational diabetics than in the normal patients (cumulated series, $P<0.001$ ). In contrast the glucose concentration in fetuses of gestational diabetics showed a tendency to be lower than that of the fetuses of normal mothers $(0.05<\mathrm{P}<0.10)$; there is thus clear separation between the normal and gestational diabetic groups in terms of the mean maternal-fetal fasting plasma glucose difference of $6.5 \mathrm{mg} / 100$ $\mathrm{ml}$ for the normal infusion series $(8.0 \mathrm{mg} / 100 \mathrm{ml}$ for the

TABLE II-Glucose Values in Four Patients with Severe Insulin-treated Diabetes after Maternal 25-g Intravenous Glucose Pulse

\begin{tabular}{|c|c|c|c|c|c|}
\hline \multirow{3}{*}{$\begin{array}{l}\text { Case } \\
\text { No. }\end{array}$} & & \multirow{3}{*}{$\begin{array}{c}\text { Maternal } / \\
\text { Fetal }\end{array}$} & \multicolumn{3}{|c|}{ Plasma Glucose $(\mathrm{mg} / 100 \mathrm{ml})$} \\
\hline & & & \multirow{2}{*}{ Fasting } & \multicolumn{2}{|c|}{ Glucose Plateau } \\
\hline & & & & Mean & Range \\
\hline $\begin{array}{l}14 \\
15 \\
16 \\
17\end{array}$ & $\left\{\begin{array}{l}\{ \\
\{\end{array}\right.$ & $\begin{array}{l}\text { M. } \\
\text { F. } \\
\text { M. } \\
\text { F. } \\
\text { M. } \\
\text { F. } \\
\text { M. } \\
\text { F. }\end{array}$ & $\begin{array}{r}137 \\
94 \\
175 \\
120 \\
106 \\
68 \\
79 \\
65\end{array}$ & $\begin{array}{l}205 \\
142 \\
215 \\
160 \\
152 \\
106 \\
189 \\
105\end{array}$ & $\begin{array}{l}182-230 \\
131-158 \\
208-221 \\
156-164 \\
149-156 \\
104-108 \\
188-190 \\
104-106\end{array}$ \\
\hline
\end{tabular}

TABLE III-Mean Fasting Plasma Glucose and Insulin Values for Infusion Series and "Cumulated Patient Series." Data from Latter Group (see text) are Given in Parentheses

\begin{tabular}{|c|c|c|c|c|c|c|c|}
\hline & \multirow{2}{*}{ Patient } & \multicolumn{3}{|c|}{$\begin{array}{c}\text { Glucose } \\
(\mathrm{mg} / 100 \mathrm{ml})\end{array}$} & \multicolumn{3}{|c|}{$\underset{(\mu \mathrm{U} / \mathrm{ml})^{*}}{\text { Insulin }}$} \\
\hline & & No. & Mean & $\begin{array}{l}\text { S.E. of } \\
\text { Mean }\end{array}$ & No. & Mean & $\begin{array}{l}\text { S.E. of } \\
\text { Mean }\end{array}$ \\
\hline Mother & $\begin{array}{l}\text { Normal .. } \\
\begin{array}{l}\text { Gestational } \\
\text { diabetic }\end{array} \\
\text { Severe insulin- }\end{array}$ & $\begin{array}{c}8 \\
(21) \\
5 \\
(9)\end{array}$ & $\begin{array}{c}67 \cdot 5 \\
(71 \cdot 2) \\
79 \cdot 6 \\
(85 \cdot 7)\end{array}$ & $\begin{array}{c}3 \cdot 8 \\
(2 \cdot 3) \\
5 \cdot 3 \\
(4 \cdot 0)\end{array}$ & \begin{tabular}{|c|}
8 \\
$(16)$ \\
5 \\
$(8)$
\end{tabular} & $\begin{array}{l}15 \cdot 1 \\
(13 \cdot 8) \\
15 \cdot 9 \\
(14 \cdot 3)\end{array}$ & $\begin{array}{r}+3.6-2.8 \\
(+2.7-2.4) \\
+5.3-4.0 \\
(+2.9-2.5)\end{array}$ \\
\hline Fetus & $\begin{array}{l}\text { treated diabetic } \\
\text { Normal .. } \\
\text { Gestational } \\
\text { diabetic } \\
\begin{array}{c}\text { Severe insulin- . } \\
\text { treated diabetic }\end{array}\end{array}$ & $\begin{array}{c}4 \\
7 \\
(20) \\
5 \\
(9) \\
4\end{array}$ & $\begin{array}{c}124 \cdot 2 \\
61 \cdot 0 \\
(63 \cdot 2) \\
52 \cdot 6 \\
(54 \cdot 1) \\
86 \cdot 7\end{array}$ & $\begin{array}{c}20 \cdot 6 \\
3 \cdot 1 \\
(2 \cdot 5) \\
6 \cdot 6 \\
(5 \cdot 1) \\
12 \cdot 8\end{array}$ & \begin{tabular}{|c|}
8 \\
$(21)$ \\
5 \\
$(9)$
\end{tabular} & $\begin{array}{l}12 \cdot 7 \\
(11 \cdot 3) \\
19 \cdot 2 \\
(15 \cdot 9)\end{array}$ & $\begin{array}{r}+1.2-1.2 \\
(+1.0-1.0) \\
+3.1-2.7 \\
(+2.5-2.2)\end{array}$ \\
\hline
\end{tabular}

* Non-insulin treated patients only; calculation from log-transformed data.
TABLE IV-Mean Plasma Glucose and Insulin Values for Glucose Infusions Number of Patients in Each Group Shown in Parentheses

\begin{tabular}{|c|c|c|c|}
\hline Patient Group & $\begin{array}{c}\text { Maternal/ } \\
\text { Fetal }\end{array}$ & $\begin{array}{c}\text { Plateau Plasma } \\
\text { Glucose } \\
\text { (Mean } \pm \text { S.E. } \\
\text { of Mean) } \\
\text { in } \mathrm{mg} / 100 \mathrm{ml}\end{array}$ & $\begin{array}{c}\text { Peak Plasma Insulin } \\
\text { (Mean } \pm \text { S.E. of Mean) } \\
\text { in } \mu U / m l \\
\text { (from } \log \text { Data) }\end{array}$ \\
\hline 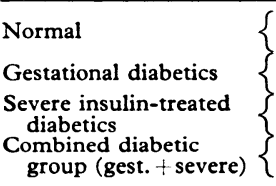 & $\begin{array}{l}\text { M. } \\
\mathrm{F} . \\
\mathrm{M} . \\
\mathrm{F} . \\
\mathrm{M} . \\
\mathrm{F} . \\
\mathrm{M} . \\
\mathrm{F} .\end{array}$ & $\begin{array}{l}222 \pm 18 \text { (7)* } \\
168 \pm 9 \cdot 6(7)^{*} \\
239 \pm 23 \quad(5) \\
157 \pm 8 \cdot 4(5) \\
190 \pm 14(4) \\
128 \pm 13 \cdot 6(4) \\
217 \pm 16 \quad(9) \\
144 \pm 8 \cdot 7(9)\end{array}$ & $\begin{array}{c}140+21=19(8) \\
36 \cdot 5+7 \cdot 0=5 \cdot 9(8) \\
48 \cdot 7+16.5=12 \cdot 4(5) \\
59 \cdot 7+22 \cdot 9-16.6(5)\end{array}$ \\
\hline
\end{tabular}

* Excluding Case 6.

cumulated series) and $27.0 \mathrm{mg} / 100 \mathrm{ml}$ for the gestational diabetic infusion series $(31.6 \mathrm{mg} / 100 \mathrm{ml}$ for the cumulated series). The four insulin-treated diabetic mothers had an even higher mean fasting plasma glucose level, and although the mean fetal value for this group was above that of the normal or gestational diabetic fetuses the mean maternal-fetal glucose difference of $37.5 \mathrm{mg} / 100 \mathrm{ml}$ was higher than that of the normal or gestational diabetic patients.

The plateau plasma glucose values attained during glucose infusions or after glucose pulses showed definite trends. Varying rates of glucose infusion were used but despite maternal plateau values of up to over $300 \mathrm{mg} / 100 \mathrm{ml}$ only one fetus (Case 6) reached a plateau glucose level of appreciably more than $200 \mathrm{mg} /$ $100 \mathrm{ml}$; this fetus developed asphyxia with accompanying tachycardia and acidosis shortly after the start of the infusion. It is possible that the high glucose concentration in this fetus may have been caused by increased mobilization or decreased tissue uptake of glucose in response to stress, and for this reason values from this patient have not been included in the determination of the mean plateau glucose values shown in Table IV. The mean maternal plateau values of 222 and $217 \mathrm{mg} /$ $100 \mathrm{ml}$ in the normal and "combined diabetic" groups respectively are very close to one another. In contrast there is a small but significant difference $(P<0.05)$ between the normal and combined diabetic fetal plateaux, the latter being lower.

\section{INSULIN VALUES}

Mean insulin values were calculated from log-transformed data, to conform to the accepted distribution of plasma insulin concentrations, fasting and after glucose (Turner et al., 1971; Welborn, Rubenstein, Haslam, and Fraser, 1966). 
Mean fasting maternal plasma insulin levels (Table III) were similar in the gestational and diabetic mothers but the mean fasting fetal concentration for the gestational diabetic group was higher than normal ( $P<0.05$ for the cumulated series) despite the lower glucose values of the fetuses of diabetic mothers.

Peak plasma insulin concentrations attained during glucose infusions are shown in Table I, with mean values in Table IV. The mean value for the gestational diabetic mothers was less than normal $(\mathrm{P}<0.001)$, confirming their diabetic status. Significant rises were observed in all fetuses studied (except in Case 5, where samples beyond 10 minutes could not be taken) although fetal and neonatal insulin responses to hyperglycaemia are known to be variable (Coltart et al., 1969; Gentz, Warrner, Persson, and Cornblath, 1969); the largest increases were seen in the gestational diabetics, and the mean peak insulin value for the diabetic group was slightly higher $(P=0 \cdot 10)$ than that for the fetuses with normal mothers. Illustrative normal and gestational diabetic cases are shown in Figs. 1 and 2.
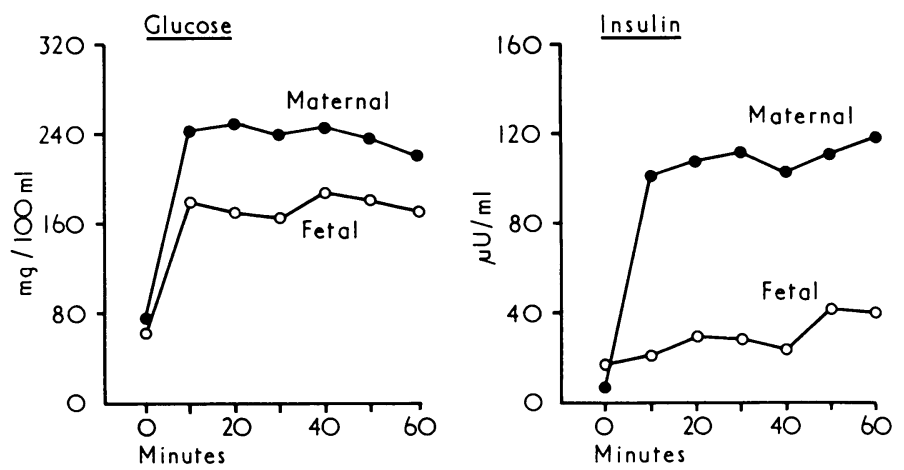

FIG. 1-Case 4 (normal). Plasma glucose and insulin values during 60minute maternal glucose infusion.
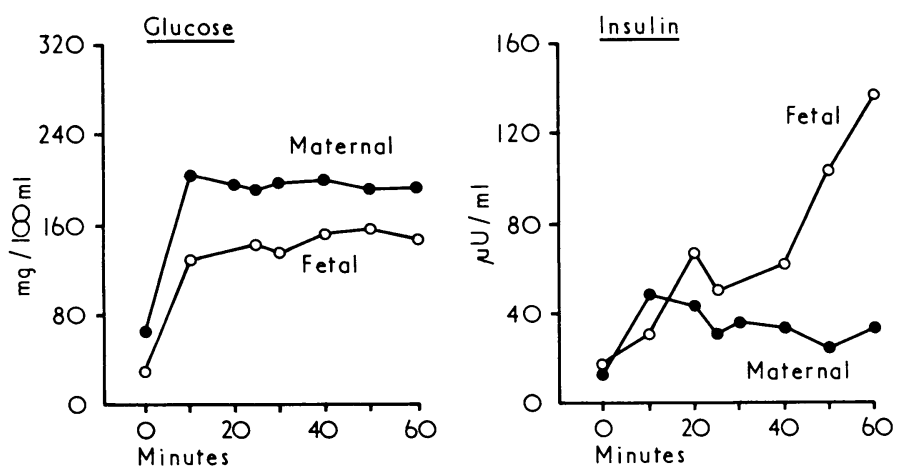

FIG. 2-Case 10 (gestational diabetes). Plasma glucose and insulin values during 60-minute glucose infusion.

\section{Discussion}

The fetal scalp has been much criticized as a reliable site for the collection of samples that are supposed to represent blood passing through the fetus from the placenta. It is therefore encouraging that the pattern of fasting glucose and insulin values observed in the infusion series and the cumulated series is so consistent. A major factor contributing to this consistency is that all studies were performed under steady-state conditions before the onset of labour.

Our results show that so long as the plasma glucose of a normal mother stays within physiological limits a maternal-fetal plasma glucose difference of less than $20 \mathrm{mg} / 100 \mathrm{ml}$ is maintained, suggesting that in these conditions the fetus equilibrates through the placenta with the mother. When the plasma glucose of a normal mother is raised well above the physiological range that of her fetus rises to a plateau at a substantially lower level, usually in the range $150-200 \mathrm{mg} / 100 \mathrm{ml}$. This finding, which is in agreement with that of Sabata, Frerichs, Wolf, and Stubbe (1970), suggests that there is probably an upper limit of maternal hyperglycaemia beyond which a further increase does not affect the fetal level. A possible explanation for this is that the facilitated diffusion system in the placenta (Widdas, 1961) is saturated by a high maternal glucose concentration.

In diabetic pregnancy the fasting fetal glucose values are lower and fasting maternal values higher than in normal pregnancy; a similar fetal trend is seen with sustained maternal hyperglycaemia. It seems likely that this can be ascribed to the associated fetal hyperinsulinism which was shown. Fasting hyperinsulinism was reported by Thomas, de Gasparo, and Hoet (1967) and by Obenshain et al. (1970) but this is the first report of an exaggerated fetal insulin response to glucose in diabetic pregnancy. The extent to which impaired placental glucose transport and increased placental glucose utilization contribute to the regulation of the fetal glucose level in diabetic pregnancies is not known.

The results of this study may provide a clue towards the cause of fetal death in diabetic pregnancies. The observation of hyperinsulinism in the fetuses of diabetic mothers, both fasting and after a glucose load, is likely to be the consequence of the islet hypertrophy found in these fetuses by Cardell (1953). In conditions of maternal hyperglycaemia limited placental glucose transport and fetal hyperinsulinism combine to maintain the fetal plasma glucose concentration within the normal range. In fasting conditions, however, when the supply of glucose from the mother is greatly diminished hyperinsulinism apparently persists and could be responsible for severe fetal hypoglycaemia.

The adverse effects of hypoglycaemia on the fetus are not certain. On the one hand, maternal hypoglycaemia in late pregnancy is not regarded as a severe hazard to the fetus while, on the other hand, symptomatic neonatal hypoglycaemia may cause severe brain damage (Blattner, 1968; Haworth and McRae, 1965). In normal women (Paterson, Page, Taft, Phillips, and Wood, 1968) and monkeys (Chez, Mintz, Horger, and Hutchinson, 1970) acute depression of maternal plasma glucose by exogenous insulin is associated with only mild depression of the fetal level, which sometimes becomes higher than that of the mother. This apparent resistance to maternal hypoglycaemia may depend on the ability of the normal fetus greatly to reduce its rate of glucose uptake or to mobilize its stores of glycogen. The actual fetal plasma glucose concentration is, however, only one factor, and tolerance of hypoglycaemia may also depend on the availability of alternative substrates such as free fatty acids and ketones for peripheral and cerebral metabolism; insulin may act by accelerating the net disposal of glucose, thus depressing the blood sugar, and also by lowering the plasma concentration of these alternative substrates. That insulin does more than just lower the plasma glucose is suggested by the observation that hypoglycaemia is accompanied by symptoms in the neonate only when the plasma insulin level is abnormally high (Cornblath, et al., 1966).

Three clinical observations are consistent with the hypothesis that fetal hypoglycaemia induced by hyperinsulinism contributes to the perinatal mortality in diabetic pregnancy. Firstly, intrauterine death is most common near term, when the human fetal pancreas is fully mature and hyperinsulinism is likely to be maximal. Secondly, strict control of the blood sugar of the diabetic during the second half of pregnancy is known to lower perinatal mortality; it also ensures that the stimulus of hyperglycaemia to the fetal pancreatic islet is less, which probably leads to a reduction in hyperinsulinism and subsequent hypoglycaemia. Thirdly, increased fetal weight and fetal loss are known to characterize the prediabetic and early diabetic years as well as those when the disease is fully established-an observation that has always been difficult to explain; it may be that the pronounced fluctuations between hyperglycaemia and hypoglycaemia that occur in the early years of diabetes (Seltzer, Fajans, and Conn, 1956) are particularly dangerous to the fetus, stimulating hyperinsulinism with associated exposure to intermittent maternal hypoglycaemia. 
We wish to acknowledge the help of Mr. J. M. Brudenell, Dr. W. G. Oakley, Dr. D. A. Pyke, Mr. G. D. Pinker, Dr. C. A. Young, Mr. R. L. Lloyd-Jones, and Dr. J. D. N. Nabarro for allowing us to study their cases; Professor V. Wynn, in whose laboratory the biochemical estimations were performed, for his support and encouragement; Miss Cynthia Knight and Miss Evelyn Kissin for technical assistance; Dr. Julia Ellis for providing the insulin antiserum used in some of the assays; and the British Diabetic Association for research grants (N.W.O. and R.C.T.).

\section{References}

Albano, J., Ekins., R. P., Maritz, G., and Turner, R. C. (1972). Acta Endocrinologica. In press.

Beard, R. W., Turner, R. C., and Oakley, N. W. (1971). Postgraduate Medical fournal, 47, Jan. Suppl., p. 68.

Blattner, J. R. (1968). Fournal of Pediatrics, 72, 904.

Blattner, J. R. (1968). Fournal of Pediatrics, 72, 904.

Cardell, B. S. (1953). Fournal of Pathology and Bacteriology, 66, 335. fournal of Clinical Investigation, 49, 1517.
Coltart, T. M., Beard, R. W., Turner, R. C., and Oakley, N. W. (1969). British Medical fournal, 4, 17.

Cornblath, M., Joassin, G., Weisskopf, B., and Swiatek, K. R. (1966). Pediatric Clinics of North America, 13, 905.

Cramp, D. G. (1967). Fournal of Clinical Pathology, 20, 910.
Farquhar, J. W. (1956). Archives of Disease in Childhood, 31, 203.

Farquhar, J. W. (1956). Archives of Disease in Childhood, 31, 203. Acta Paediatrica Scandinavica, 58, 481 .

Haworth, J. C., and McRae, K. N. (1965). Canadian Medical Association fournal, 92, 861 .

Oakley, W. G. (1965). In On the Nature and Treatment of Diabetes, ed. B. S. Leibel and G. A. Wrenshall, p. 673. Amsterdam, Excerpta Medica.

Obenshain, S. S., et al. (1970). New England fournal of Medicine, 283, 566.

Paterson, P., Page, D., Taft, P., Phillips, L., and Wood, C. (1968). Fournal of Obstetrics and Gynaecology of the British Commonwealth, 75, 917.

Pedersen, J., and Brandstrup, E. (1956). Lancet, 1, 607.

Sabata, V., Frerichs, H., Wolfe, H. and Stubbe, P. (1970). Fournal of Obstetrics and Gynaecology of the British Commonwealth, 77, 121 .

Saling, E. (1964). Zeitschrift für Geburtshilfe und Gynäkologie, 162, 56.

Seltzer, H. S., Fajans, S. S., and Conn, J. W. (1956). Diabetes, 5, 437.

Turner, R. C., Oakley, N. W., and Nabarro, J. D. N. (1971). British Medical Fournal, $2,132$.

Thomas, K., Gasparo, M. de, and Hoet, J. J. (1967). Diabetologia, 3, 299.

Welborn, T. A., Rubenstein, A. H., Haslam, R., and Fraser, R. (1966). Lancet, 1, 280.

Widdas, W. F. (1961). British Medical Bulletin, 17, 107.

\title{
Syndrome of Rapid Irregular Movements of Eyes and Limbs in Childhood
}

\author{
G. PAMPIGLIONE, MARIA MAIA
}

British Medical fournal, 1972, 1, 469-473

\section{Summary}

Electroencephalographic (E.E.G.), polyelectromyographic (poly-E.M.G.), and electro-oculographic (E.O.G.) studies were made of 16 young children and babies referred because of prolonged episodes of rapid irregular movements of eyes and limbs (R.I.M.E.L.) sometimes involving also the trunk and head. This unusual syndrome of unknown aetiology developed over a period of a few days and persisted for months or years. In the E.E.G. there were only minor changes, without discharges of any kind during the episodes of involuntary movements, and during sleep the spindles were unusually fast. In the poly-E.M.G. single or multiple spikes appeared as electrical concomitants of brief myoclonic phenomena at irregular intervals and independently in the various groups of muscles examined. In the E.O.G. the frequent episodes of irregular jerky movements of the eyeballs occurred at various intervals and without rhythmicity. On clinical observation alone this syndrome may not be easily separated from other conditions such as myoclonic epilepsy, gross ataxia, tremors, or choreiform syndromes in young children; the peculiar combination of neurophysiological findings is essential in the identification of this unusual disorder.

\section{Introduction}

In recent years reports have appeared in the literature of infants affected by involuntary movements of the eyeballs, of the limbs, and sometimes also of the trunk, head, and face. Such cases have been described under a variety of names from

\footnotetext{
Department of Neurophysiology, the Hospital for Sick Children, Great Ormond Street, London W.C.1

G. PAMPIGLIONE, M.D., F.R.C.P., Physician in Charge

MARIA MAIA, M.D., Research Assistant, Honorary Registrar
}

"myoclonic encephalopathy of infants" (Kinsbourne, 1962), "ocular oscillations and truncal myoclonus" (Baringer et al., 1968), "dancing eyes, dancing feet, polymyoclonia" (Dyken and Kolár, 1968) to "infantile polymyoclonia-opsoclonus" (Moe and Nellhaus, 1970). Moreover, some of these unusual motor phenomena have been described in young children with neuroblastoma as "oculo-cerebello-myoclonic syndrome" (Lemerle et al., 1969). However, from the purely clinical descriptions in the literature it is not easy to understand whether the involuntary movements reported under these different names are similar or different phenomena.

The present contribution is based on neurophysiological studies of 16 young children and infants referred to our department because of a syndrome of rapid irregular involuntary movements of the limbs, trunk, head, and eyeballs developing over a period of a few days and persisting for months or years. It seems possible from the neurophysiological findings to identify an unusual clinical syndrome, the aetiology of which is still unknown. We propose in this paper to refer to this syndrome as R.I.M.E.L. (rapid irregular movements of eyes and limbs) referring to the most obvious symptoms and avoiding confusion with other conditions, such as myoclonic epilepsy, ataxia, tremors, and choreo-athetosis.

\section{Patients and Methods}

All the 16 children ( 5 boys and 11 girls) had been admitted to our hospital under the care of one or another member of the staff, but most of them were followed up in the neurological wards. Some clinical features of 6 of the 16 cases in the present paper have been previously reported by Kinsbourne (1962) and these children are included in the present paper with a somewhat different emphasis. The neurophysiological studies included electroencephalography (E.E.G.), polyelectromyography (poly-E.M.G.), and electro-oculography (E.O.G.) with a total of 94 records. Some of the patients were followed up for several years. A cine film was taken of nine children either during or soon after the neurophysiological investigations in order to document some of the odd movements. 